\title{
Oral contraceptive induced chorea: another condition associated with anti-basal ganglia antibodies
}

\author{
M Miranda, F Cardoso, G Giovannoni, A Church
}

Use of oral contraceptives is a recognised but infrequent cause of chorea. This type of chorea has usually been considered a reactivation of Sydenham's chorea by an unknown mechanism. A patient developed a chorea triggered by the use of oral contraceptives with no definite evidence of previous Sydenham's chorea or recent streptoccocal infections. However, the patient had positive anti-basal ganglia antibodies, which supports an immunological basis for the pathophysiology of this chorea.

U se of oral contraceptives is a well known but uncommon cause of chorea.$^{12}$ It has been hypothesised that this condition is due to reactivation of Sydenham's chorea but this antecedent has been absent in some patients, whereas other cases have been related to the development of other autoimmune disorders such as systemic lupus erythematosus. ${ }^{3}$ To our knowledge, there have been no reports of an association of this form of chorea with the presence of anti-basal ganglia antibodies, a condition that would support an immunological mechanism for the pathogenesis of this disorder.

\section{CASE REPORT}

In March 2001, a 19 year old female college student, who was previously healthy, developed abnormal facial grimacing and writhing movements of her left hand. These abnormal movements came on insidiously and followed a stable course over a year with neither exacerbation nor remission. She did not describe premonitory urges and could not control these movements at will. Her college performance was unaffected and there was no evidence of cognitive or psychiatric manifestations; specifically there was no obsessive-compulsive behaviour. One year prior to the onset of these movements she had begun taking an oral contraceptive (OC), which contained ciproterona $2 \mathrm{mg}$ and ethinylestradiol $0.035 \mathrm{mg}$, for a menstrual irregularity. She had never been pregnant. There was no personal or family history of abnormal movements and no previous history of rheumatic fever. There was no history of an antecedent streptococcal or other infection.

General medical examination was normal. Specifically, cardiac auscultation revealed no abnormalities. On neurological examination, the most relevant finding was the presence of facial grimacing, mainly affecting her lower face, and choreiform movements of the left hand. Neurological examination revealed no cognitive, pyramidal, sensory, cerebellar, or gait abnormalities. She complained that these abnormal movements, in spite of being mild, impaired her social functioning.

The laboratory evaluation revealed a raised anti-streptolysin-O titre of $287 \mathrm{IU} / \mathrm{ml}$ (normal $<200 \mathrm{IU} / \mathrm{ml}$ ). However, the
anti-DNAase B titre of $120 \mathrm{IU} / \mathrm{ml}$ was normal (normal $<340 \mathrm{IU} / \mathrm{ml}$ ). Throat cultures did not detect streptococcus. Her full blood count, erythrocyte sedimentation rate, Creactive protein, thyroid function, plasma amino acids, ceruloplasmin, antinuclear antibodies, and antiphospholipid antibodies were either normal or negative. Magnetic resonance imaging of the brain was normal. Echocardiogram showed no alterations. Anti-basal ganglia antibodies were positive by Western immunoblotting and revealed reactivity against antigens of 40 and $45 \mathrm{kDa}$ in size. The antibody assay method has been described previously. ${ }^{4}$ The patient's serum was also screened against a liver antigen preparation to exclude non-specific binding as a result of antinuclear factors or other auto-antibodies. These specific 40 and $45 \mathrm{kDa}$ bands appear to be relatively specific for the group of disorders associated with anti-basal ganglia antibodies. ${ }^{4}$

Her neurological symptoms gradually subsided 2 months after initiating treatment with sulpiride $300 \mathrm{mg}$ daily and the withdrawal of the OCP. Neurological examination 2 months after stopping the sulpiride therapy was normal.

\section{DISCUSSION}

In 1966, Fernando reported the first description of chorea associated with use of OCs. ${ }^{1}$ Subsequently, reports by Lewis, ${ }^{5}$ Gamboa, ${ }^{6}$ and Nausieda ${ }^{2}$ established OCs as a cause of chorea, although this association is uncommon. Table 1 reviews the clinical features of the cases reported in the literature over the last 23 years. Some cases have been considered to be caused by reactivation of Sydenham's chorea, ${ }^{28}$ while in others no clear relationship with Sydenham's chorea or streptococcal infection has been established. ${ }^{10}$ The recurrence of chorea during pregnancy in some of these cases suggests a role of oestrogens in these disorders. ${ }^{11}$ However, immunologically mediated disorders such as systemic lupus erythematosus and antiphospholipid antibody syndrome must be ruled out in these patients even in the presence of a past history of chorea induced by OCs. ${ }^{3}{ }^{12}$ None of these disorders was detected in our patient. The asymmetrical features at presentation in our patient is not unusual and has been reported in other cases of OCP associated chorea ${ }^{2}$ and in patients with Sydenham's chorea. ${ }^{13}$

To the best of our knowledge, this is the first report of a case of chorea associated with the use of the OCs in which anti-basal ganglia antibodies have also been detected. This suggests that there may be an immunological basis in the pathogenesis of this disorder. The hypothesis of an immune reaction associated with this condition is not new; in fact Gamboa et al in $1971^{6}$ were the first to postulate an immunological mechanism in the pathogenesis of this condition. An immunological reaction associated with the

Abbreviations: OC, oral contraceptive 
Table 1 Clinical features of patients with chorea associated with the use of oral contraceptives in the last 23 years

\begin{tabular}{|c|c|c|c|c|c|c|}
\hline Reference & $\begin{array}{l}\text { Patient } \\
\text { age } \\
\text { (years) }\end{array}$ & $\begin{array}{l}\text { Time } \\
\text { of use }\end{array}$ & $\begin{array}{l}\text { Duration } \\
\text { of chorea } \\
\text { (weeks) }\end{array}$ & $\begin{array}{l}\text { Clinical } \\
\text { presentation/ } \\
\text { onset }\end{array}$ & Medical history & Comments \\
\hline \multirow[t]{5}{*}{ Nausieda ${ }^{2}$} & 20 & 12 weeks & 1 & $\begin{array}{l}\text { Hemichorea/ } \\
\text { insidious }\end{array}$ & $\begin{array}{l}\text { Congenital } \\
\text { cardiopathy }\end{array}$ & \\
\hline & 17 & 2 weeks & 2 & $\begin{array}{l}\text { Bilateral/ } \\
\text { insidious }\end{array}$ & $\begin{array}{l}\text { Sydenham̈'s } \\
\text { chorea }\end{array}$ & \\
\hline & 18 & 8 weeks & 3 & $\begin{array}{l}\text { Bilateral/ } \\
\text { insidious }\end{array}$ & $\begin{array}{l}\text { Sydenham̈'s } \\
\text { chorea }\end{array}$ & \\
\hline & 21 & 2 weeks & 2 & $\begin{array}{l}\text { Bilateral/ } \\
\text { insidious }\end{array}$ & $\begin{array}{l}\text { Congenital } \\
\text { cardiopathy }\end{array}$ & \\
\hline & 20 & 11 weeks & 2 & $\begin{array}{l}\text { Hemichorea/ } \\
\text { insidious }\end{array}$ & Purpura & Normal pregnancy \\
\hline Dove $^{7}$ & 20 & 8 months & 8 & $\begin{array}{l}\text { Hemichorea/ } \\
\text { insidious }\end{array}$ & Rheumatic fever & 2 normal pregnancies \\
\hline Greene $^{8}$ & 16 & 2 months & 8 & $\begin{array}{l}\text { Bilateral/ } \\
\text { insidious }\end{array}$ & $\begin{array}{l}\text { Sydenham's } \\
\text { chorea }\end{array}$ & Chorea gravidarum \\
\hline \multirow[t]{2}{*}{ Buge $^{9}$} & 26 & 2 months & 6 & $\begin{array}{l}\text { Hemichorea/ } \\
\text { insidious }\end{array}$ & None & \\
\hline & 23 & 8 years & 2 & $\begin{array}{l}\text { Hemichorea/ } \\
\text { insidious }\end{array}$ & & Normal pregnancy \\
\hline Berger $^{10}$ & 21 & 4 years & 4 & $\begin{array}{l}\text { Hemichorea/ } \\
\text { insidious }\end{array}$ & None & Normal pregnancy \\
\hline$V^{2} a^{16}$ & 27 & $\begin{array}{l}\text { Not } \\
\text { specified }\end{array}$ & 16 & $\begin{array}{l}\text { Hemichorea/ } \\
\text { insidious }\end{array}$ & None & $\begin{array}{l}\text { PET with FDG showed } \\
\text { increased glucose } \\
\text { metabolism in contralateral } \\
\text { caudate nucleus }\end{array}$ \\
\hline $\begin{array}{l}\text { Present } \\
\text { case }\end{array}$ & 19 & 2 years & 57 & $\begin{array}{l}\text { Hemichorea/ } \\
\text { insidious }\end{array}$ & None & $\begin{array}{l}\text { Presence of anti-basal } \\
\text { ganglia antibodies }\end{array}$ \\
\hline
\end{tabular}

use of OCs has also been proposed as an explanation for the cases of chorea as the initial manifestation of systemic lupus erythematosus, ${ }^{3}$ or antiphospholipid antibody syndrome. ${ }^{12}$

We acknowledge that to have circulating antibodies does not necessarily imply causation; these antibodies have been described in several conditions such as Sydenham's chorea and rheumatic fever, ${ }^{4}$ acute disseminated encephalomyelitis, ${ }^{14}$ and in a subgroup of Tourette syndrome patients, ${ }^{15}$ and therefore they could represent an epiphenomenon. Their pathophysiological role remains uncertain.

Recently Vela et al, using positron emission tomography with ${ }^{18} \mathrm{~F}$-fluorodeoxyglucose, reported increased glucose metabolism in the caudate nucleus of a patient with hemichorea induced by the OCs. ${ }^{16}$ This supports the direct involvement of basal ganglia circuits as part of the pathological process in these patients.

Our patient had a weakly positive ASO, but negative antiDNAse B, indicating the possibility of a recent streptococcal infection. It has been hypothesised that streptococcal infection triggers the production of anti-basal ganglia antibodies by the process of molecular mimicry. ${ }^{4}$ In our patient, a previous streptococcal infection probably induced the formation of these antibodies, which could have rendered the basal ganglia more vulnerable, and when exposed to hormones the patient developed chorea. The oestrogenic component of OCs is most likely the causative factor in the chorea induced by these agents. Oestrogens do have a definite but very complex modulatory action in dopaminergic systems, and this has been well established, for example in chorea gravidarum. ${ }^{11}$

The presence of an immunological reaction directed at the basal ganglia in this particular disorder may not have therapeutic implications. This is a very benign condition; most cases have a remission after withdrawal of the pill, usually in a period of 2-3 months.

Whether or not chorea occurring in association with pregnancy, systemic lupus erythematosus, or the antiphospholipid antibody syndrome is associated with anti-basal ganglia antibodies is unknown and requires further study.

\section{Authors' affiliations}

M Miranda, Department of Neurology, University of Chile, Chile F Cardoso, Department of Neurology, The Federal University of Minas Gerais, Brazil

G Giovannoni, A Church, Department of Neuroinflammation, Institute of Neurology, Queen Square, London WCIN 3BG, UK

Competing interest: none declared

Correspondence to: $\operatorname{Dr} M$ Miranda, Department of Neurology, University of Chile, Llewellyn Jones 1530, Suite 201, Santiago, Chile; e-mail: marcelomiranda@terra.c

Received 28 May 2003

Accepted in revised form 21 July 2003

\section{REFERENCES}

1 Fernando SJM. An attack of chorea complicating oral contraceptive therapy. Practitioner 1966;197:210-12.

2 Nausieda P, Koller W, Weiner W, et al. Chorea induced by oral contraceptives. Neurology 1979;29:1605-9.

3 Mathur AK, Gatter RA. Chorea as the initial manifestation of oral contraceptives induced lupus erythematosus. J Rheumatol 1988;6:1042-3.

4 Church A, Cardoso F, Thompson E, et al. Anti-basal ganglia antibodies in acute and persistent Sydenham's chorea. Neurology 2002;59:227-231.

5 Lewis PD. Harrison MJ. Involuntary movements in patients taking oral contraceptives. BMJ 1969;4:404-5

6 Gamboa E, Isaacs G, Harter D. Chorea associated with oral contraceptive therapy. Arch Neurol 1971;25:112-14.

7 Dove DJ. Chorea associated with oral contraceptives. Am J Obstet Gynecol 1980;137:740-2.

8 Greene PM. Chorea induced by oral contraceptives. Neurology 1980;30:11.

9 Buge A, Vincent D, Rancurel G, et al. Hemichorea and oral contraceptives. Rev Neurol 1985; 141:663-45

10 Berger E, Tatu L, Berges S, et al. Hemichorea induced by oral contraceptives. Press Med 1996;25:172.

11 Cardoso F. Chorea gravidarum. Arch Neurol 2002;59:868-70.

12 Cervera R, Aserson R, Font J, et al. Chorea in the antiphospholipid syndrome: clinical, radiologic and immunologic characteristics of 50 patients. Medicine 1997;76:203-12.

13 Cardoso F, Eduardo C, Silva AP, et al. Chorea in fifty consecutive patients with rheumatic fever. Mov Disord 1997; 12:701-3.

14 Dale RC, Church A, Cardoso F, et al. Post-streptococcal acute disseminated encephalomyelitis with basal ganglia involvement and auto-reactive antibasal ganglia antibodies. Ann Neurol 2001;50:588-95.

15 Singer H, Giulano J, Hnasen B, et al. Antibodies against human putamen in children with Tourette syndrome. Neurology 1998;50:1618-24.

16 Vela L, Singer C, Sfakianakis G, et al. Chorea and oral contraceptives. A case report with PET study. Mov Disord 2002;17(Suppl 5):S316. 